\title{
Rapid response of Helheim Glacier in Greenland to climate variability over the past century
}

\author{
Camilla S. Andresen ${ }^{1 \star}$, Fiammetta Straneo ${ }^{2}$, Mads Hvid Ribergaard ${ }^{3}$, Anders A. Bjørk ${ }^{4}$, \\ Thorbjørn J. Andersen ${ }^{5}$, Antoon Kuijpers' ${ }^{1}$, Niels Nørgaard-Pedersen ${ }^{1}$, Kurt H. Kjær ${ }^{4}$, Frands Schjøth ${ }^{6}$, \\ Kaarina Weckström ${ }^{1}$ and Andreas P. Ahlstrøm ${ }^{1}$
}

\begin{abstract}
During the early 2000s the Greenland Ice Sheet experienced the largest ice-mass loss of the instrumental record ${ }^{1}$, largely as a result of the acceleration, thinning and retreat of large outlet glaciers in West and southeast Greenland ${ }^{2-5}$. The quasi-simultaneous change in the glaciers suggests a common climate forcing. Increasing air ${ }^{6}$ and ocean ${ }^{7,8}$ temperatures have been indicated as potential triggers. Here, we present a record of calving activity of Helheim Glacier, East Greenland, that extends back to about AD 1890, based on an analysis of sedimentary deposits from Sermilik Fjord, where Helheim Glacier terminates. Specifically, we use the annual deposition of sand grains as a proxy for iceberg discharge. Our record reveals large fluctuations in calving rates, but the present high rate was reproduced only in the 1930s. A comparison with climate indices indicates that high calving activity coincides with a relatively strong influence of Atlantic water and a lower influence of polar water on the shelf off Greenland, as well as with warm summers and the negative phase of the North Atlantic Oscillation. Our analysis provides evidence that Helheim Glacier responds to short-term fluctuations of large-scale oceanic and atmospheric conditions, on timescales of 3-10 years.
\end{abstract}

The forcings behind the rapid increase in mass loss from the Greenland Ice Sheet in the early 2000s (ref. 1) are still debated. It is unclear whether the mass loss will continue in the near future and, if so, at what rate. These uncertainties are a consequence of our limited understanding of mechanisms regulating ice-sheet variability and the response of fast-flowing outlet glaciers to climate variability. In southeast Greenland, Helheim Glacier, one of the regions largest glaciers, thinned, accelerated and retreated during the period 2003-2005 (ref. 4) and although it has since slowed down and readvanced $^{9}$, it has still not returned to its pre-acceleration flow rates.

It has been suggested that warming ${ }^{8,10}$ and/or inflow variability $^{11,12}$ of the nearby subsurface ocean currents triggered the acceleration, but to establish a causal relationship between glacier and climate variability, long-term records are needed. Here we present three high-resolution (1-3 years per sample) sedimentary records from Sermilik Fjord (Fig. 1 and Supplementary Information) that capture the 2001-2005 episode of mass loss, and use them to reconstruct the calving variability of Helheim Glacier over the past 120 years. Next, this record is compared with records of climate indices.
Helheim Glacier discharges in the deep (600-900 m) Sermilik Fjord, which is connected with two deep troughs $(500-700 \mathrm{~m})$ that transect the shallow shelf $(100-200 \mathrm{~m})$ allowing exchange with shelf waters. The fjord is characterized by an upper 100-150-m-thick layer of polar water from the East Greenland Current and a deeper layer $\left(500 \mathrm{~m}\right.$ thick) of warm $\left(3.5-4{ }^{\circ} \mathrm{C}\right)$ and saline Atlantic water from the North Atlantic Current ${ }^{11}$, with the latter primarily driving submarine melting ${ }^{12}$. At the northern end, the fjord branches into three smaller fjords, each containing calving glaciers. Of these, Helheim Glacier is one of the most prolific iceberg exporters in Greenland ${ }^{1}$, whereas the two northern glaciers, Midgaard and Fenris glaciers, are smaller and far less discharging ${ }^{13}$. The fjord is mostly sea-ice covered from January to June and a large ice mélange extends year-round in front of Helheim Glacier.

Three sediment cores were collected (Fig. 1) and age models for the past 120 years were established on the basis of ${ }^{210} \mathrm{~Pb}$ geochronology (Supplementary Fig. S2). The massive diamicton facies in the cores is produced by delivery of heterogeneous debris from drifting icebergs, commonly referred to as ice-rafted debris (IRD; clay, silt, sand and pebbles), and the down-fjord diminishing input of fine mud (clay and silt) suspended in the turbid meltwater plume extending from the base of Helheim Glacier. This lithofacies interpretation is in accordance with the findings from other East Greenland fjords with marine-terminating glaciers ${ }^{14,15}$.

To reconstruct a record of calving activity of Helheim Glacier, it is assumed that changes in IRD deposition rate are directly related to changes in calving activity through iceberg rafting. This is supported by a study from the nearby Kangerdlugssuaq Fjord showing that the mean annual calving rate dominates the IRD deposition rates, whereas the influence of temperature on melting of icebergs is far less important ${ }^{16}$. The sand fraction is used as a proxy for IRD because sand grains are too large $(63-1,000 \mu \mathrm{m})$ to be carried in suspension by the meltwater plume and thus allow differentiation between the plume and icebergs. Accordingly, we propose that increased sand deposition reflects increased iceberg calving from Helheim Glacier and to a far lesser extent also from the Midgaard and Fenris glaciers (Supplementary Information).

Iceberg residence time in the mélange is less than a year (K. Scharrer, personal communication, 2011), implying that variations in IRD entrainment over time do not significantly affect the variability in sand deposition rates down-fjord over the investigated time span (Supplementary Information).

\footnotetext{
${ }^{1}$ Geological Survey of Denmark and Greenland, Department of Marine Geology and Glaciology, Øster Voldgade 10, 1350 Copenhagen K, Denmark, ${ }^{2}$ Department of Physical Oceanography, Woods Hole Oceanographic Institution, Woods Hole, Massachusetts 02543, USA, ${ }^{3}$ Danish Meterological

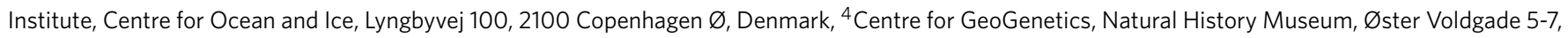
1350 Copenhagen K, Denmark, ${ }^{5}$ Institute for Geology and Geography, Øster Voldgade 10, Univ. of Copenhagen, 1350 Copenhagen K, Denmark,

${ }^{6}$ Geological Survey of Denmark and Greenland, Geological Data Centre, Øster Voldgade 10, 1350 Copenhagen K, Denmark. ^e-mail: csa@geus.dk.
} 


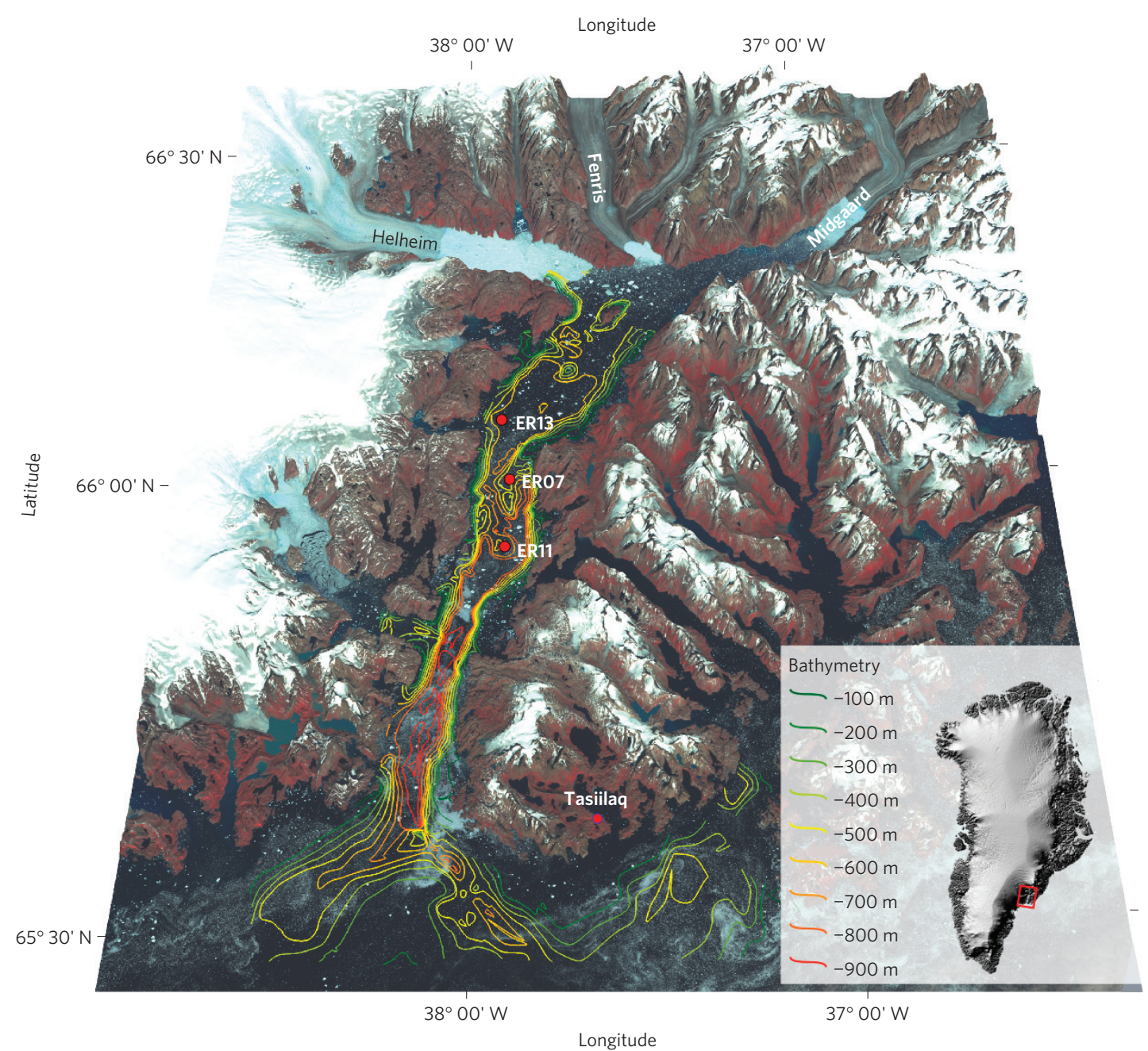

Figure 1 | Sermilik Fjord and Helheim Glacier with position of cores. The length of the fjord is about $90 \mathrm{~km}$ and the width is 5-12 km. Cores ER13, ERO7 and ER11 are retrieved from $660 \mathrm{~m}, 525 \mathrm{~m}$ and $600 \mathrm{~m}$ water depth, respectively. The bathymetry is a compilation of data obtained during cruises conducted in recent years by the Geological Survey of Denmark and Greenland, Woods Hole Oceanographic Institution, Swansea University and Nansen Environmental Remote Sensing Center (Supplementary Information). The background image is an oblique Landsat scene (L5231014_01419860911) draped over a digital elevation model.

Sand deposition rates in the three cores vary both in magnitude and variability (Fig. $2 \mathrm{a}-\mathrm{c}$ ). The mean rate decreases down-fjord, consistent with the notion that icebergs become progressively IRD depleted as they transit down-fjord ${ }^{15,17}$. Generally, the multidecadal variability is similar, but ER13, the closest to Helheim, shows higher-frequency variability than ER07 and ER11. This is attributed to the initial high particle fluxes in the meltwater plume from Helheim Glacier decaying abruptly south of ER13 (ref. 12). This favours deposition of larger amounts of suspended mud at ER13, thus diluting the IRD sand fraction and allowing a higher time resolution when compared with ER07 and ER11 (Supplementary Fig. S4). Differences in the timing of the highfrequency variability are attributed to factors such as wind, fjord circulation and sea-ice cover, which affect iceberg routing ${ }^{16}$ and hence the local iceberg rafting. Thus, to obtain a mean sand-deposition-rate time series for Sermilik Fjord, we created a composite record by averaging the sand deposition rates of the three cores (Fig. 2d) under the assumption that the average of the three cores is indicative of the mean deposition rate within most of the fjord. The validity of the composite sand deposition record as a proxy for the calving history of Helheim Glacier is supported by its agreement with changes in its front position according to satellite data and historical aerial photographs (Fig. 2d).
The reconstructed 120-year-long calving record from Helheim Glacier shows calving maxima and minima lasting 2-5 years and often bundled into longer episodes of 5-10 years. Two pronounced calving maxima are observed: one during the past 10 years, the other in the late 1930s/early 1940s. The long-term calving increase is probably due to a shift from the Little Ice Age conditions, which were characterized by low air temperatures and strong polar-water influence in the Denmark Strait region and ended after AD 1900 here $^{18}$.

Most of the climate-related mechanisms proposed to explain glacier acceleration and increased calving invoke increased local air and/or ocean temperatures. Warming summer air temperatures will increase surface melt which, in turn, can affect the glacier by increasing sliding ${ }^{19}$ (although this process is small for Helheim Glacier ${ }^{20}$ ), by destabilizing the glacier's tongue by feeding its crevasses ${ }^{21}$, or enhance submarine melting if released at depth in the fjord ${ }^{22}$. Increased ocean temperatures will also enhance submarine melt rates and, by changing the characteristics at the terminus, influence glacier stability ${ }^{7,23}$. Both ocean and air warming can reduce the level of sea-ice formation in the fjord and within the ice mélange in front of the glacier, potentially increasing the calving rate by destabilizing the glacier tongue ${ }^{17}$. 

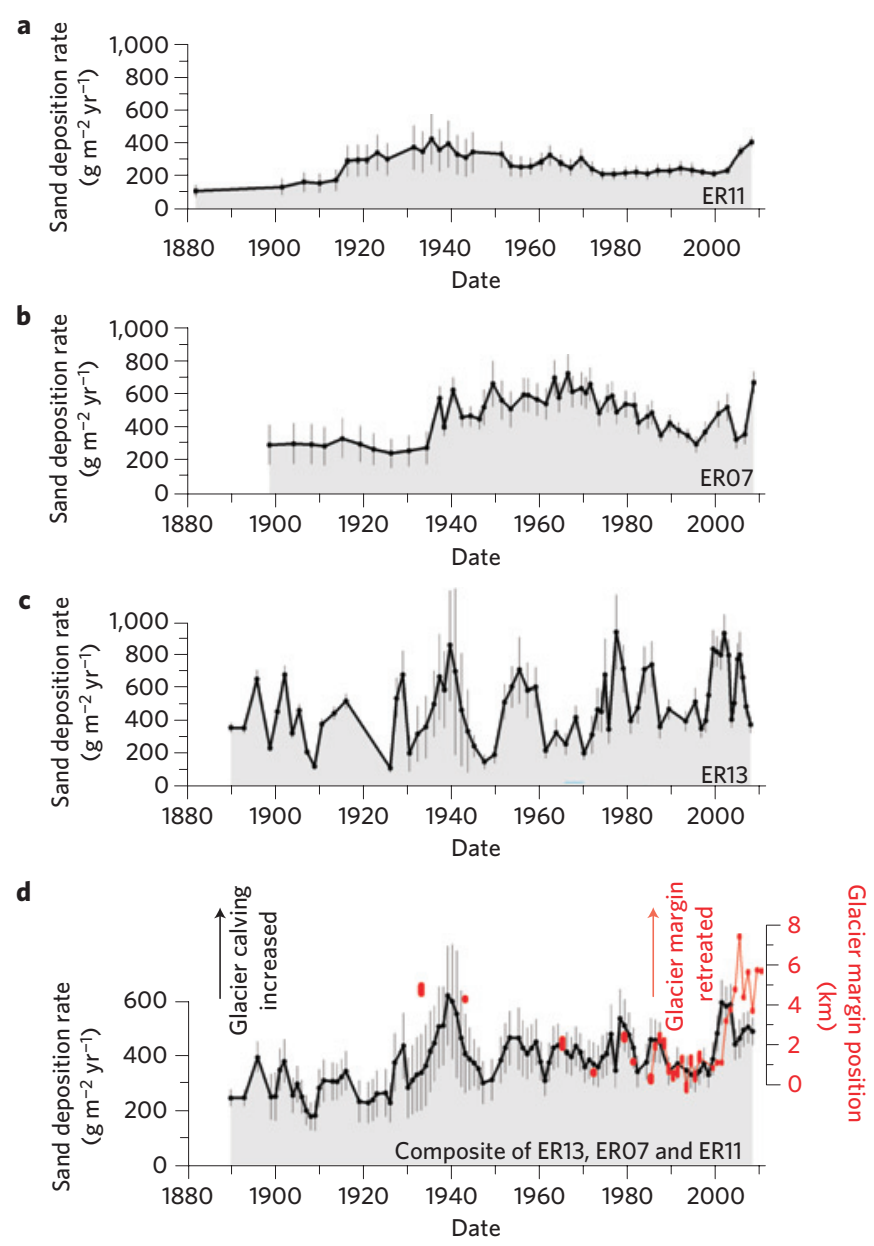

Figure $\mathbf{2}$ | Sand deposition rates in the cores. a, ER11. b, ER07. c, ER13. d, Reconstructed calving record of Helheim Glacier calculated as the average sand (63-1,000 $\mu \mathrm{m})$ deposition rate $\left(\mathrm{g} \mathrm{m}^{-2} \mathrm{yr}^{-1}\right)$ of the three cores (Supplementary Information). Error bars are a function of 1 sigma error of mass accumulation rates and sand content. The chronology of ER13 in the composite record is adjusted towards a timescale two years older (within 1 sigma error bar) during the interval 1980-2000 to improve the fit with glacier images (Supplementary Fig. S3). The glacier margin positions (red) are relative to the 1993 position according to aerial and satellite images (Supplementary Fig. S5 and Supplementary Information).

Helheim Glacier's calving record is compared with local oceanic and atmospheric variability to determine whether a statistically significant correlation exists between them (Fig. 3). Ocean variability is influenced by both the surface polar water and the subsurface Atlantic water. As there are no long-term ocean measurements from Sermilik Fjord or the nearby shelf, we rely on the upstream/near-source variability of the two watermasses (Supplementary Information) and the finding that they are continuously renewed through exchange with the shelf ${ }^{11}$. For Atlantic water we use direct measurements of sea surface temperature (SST) from a region south of Iceland where Atlantic water extends to the surface (Fig. 3b). For polar-water variability, we use changes in the northernmost multi-year sea-ice extent off southwest Greenland (storis index ${ }^{24}$ ) assuming that it is correlated with polar-water variability (Fig. 3c). Hydrographic variability on the shelf mostly reflects changes in the relative volume of Atlantic water and polar water; thus, the Atlantic-water and polarwater indices were combined into a shelf index (Fig. 3d and Supplementary Fig. S6) - a positive shelf index indicates a thicker and warmer Atlantic water (at the expense of polar water) and vice versa. The shelf index is validated through independent data sources in the Supplementary Information. Air temperature variability is taken from the observed summer temperatures near Tasiilaq ${ }^{25}$ (Fig. 3f). Finally, we examine the correlation between calving activity and the winter time North Atlantic Oscillation (NAO) inde $\mathrm{x}^{26}$, representative of the dominant mode of atmospheric climatic variability in the North Atlantic region (Fig. 3e).

Although non-climatic factors intrinsic to Helheim Glacier (for example, glacier bed topography and internal glacier dynamics) are expected to influence calving activity ${ }^{27}$, our analysis indicates that a significant fraction of the calving variability of Helheim Glacier since AD 1890 is consistent with increased Atlantic water (temperature and/or volume), decreased polar water, a positive shelf index, increased summer air temperatures and a negative NAO index as implied by significant correlations on the bulk data sets (Table 1 and Supplementary Information).

To investigate the timescales involved, we first consider the correlation between the 25-year low-pass filtered calving and climate records (Supplementary Fig. S7). This shows that on multi-decadal timescales, calving is mostly linked with synchronous changes in the source Atlantic water and the local summer air temperature, which, in turn, track the Atlantic Multi-decadal Oscillation $^{28}$. Given the regional oceanic and atmospheric covariance on these timescales, it is not possible to separate their relative contribution to glacier variability.

On shorter-term timescales (3-10 years), we find that the correlation of the residual calving variability and the residual climate variability is significant only for the NAO index and the shelf index (Table 1). The high correlation with the NAO index is expected because local winds and air temperatures as well as variability in both the polar-water and Atlantic-water source regions often co-vary with the NAO (ref. 29) on these timescales. A negative NAO phase, in particular, is associated with a warm subpolar gyre and increased penetration of Atlantic water on the shelf ${ }^{8}$. However, this analysis also indicates that episodes of increased polar-water inflow, for example the Great Salinity Anomalies between 1965 and 1972 and during the early 1980s and early 1990s (ref. 30; Fig. 3c), were associated with diminished calving activity, probably due to stabilization of the glacier terminus and mélange and/or reduced Atlantic-water penetration on the shelf.

The climate characteristics found for a composite of the ten highest short-term calving episodes ( $\mathrm{HC} 1-\mathrm{HC} 10$ in Fig. 3a and Supplementary Table S1) support the conclusion that the shelf index and the phase of the NAO are significant players in modulating short-term calving variability.

Our analysis indicates that the recent increase in calving activity observed at Helheim Glacier is not unique but that a similarly large event occurred in the late 1930s/early 1940s (HC6 Fig. 3a). These two episodes occurred at times when the temperature of the Atlantic-water source was high (positive/warm Atlantic Multidecadal Oscillation phase) and the polar-water export was at a record low (even if fluctuating). The NAO index was also frequently negative, but not markedly more than during many of the other calving episodes. Interestingly, both episodes are characterized by record high summer temperatures since 1895 (1939, 1941 and 2003). These conditions probably resulted in increased surface and submarine melt that may have contributed to the marked mass loss from Helheim Glacier.

Our study provides evidence that Helheim Glacier responds to changes in atmosphere-ocean variability on timescales as short as a few years. Therefore, the prediction of future ice-sheet mass-balance changes associated with dynamic adjustments from outlet glaciers needs to incorporate atmosphere-ocean climate models that are capable of reproducing the regional variability on these same timescales. 
f

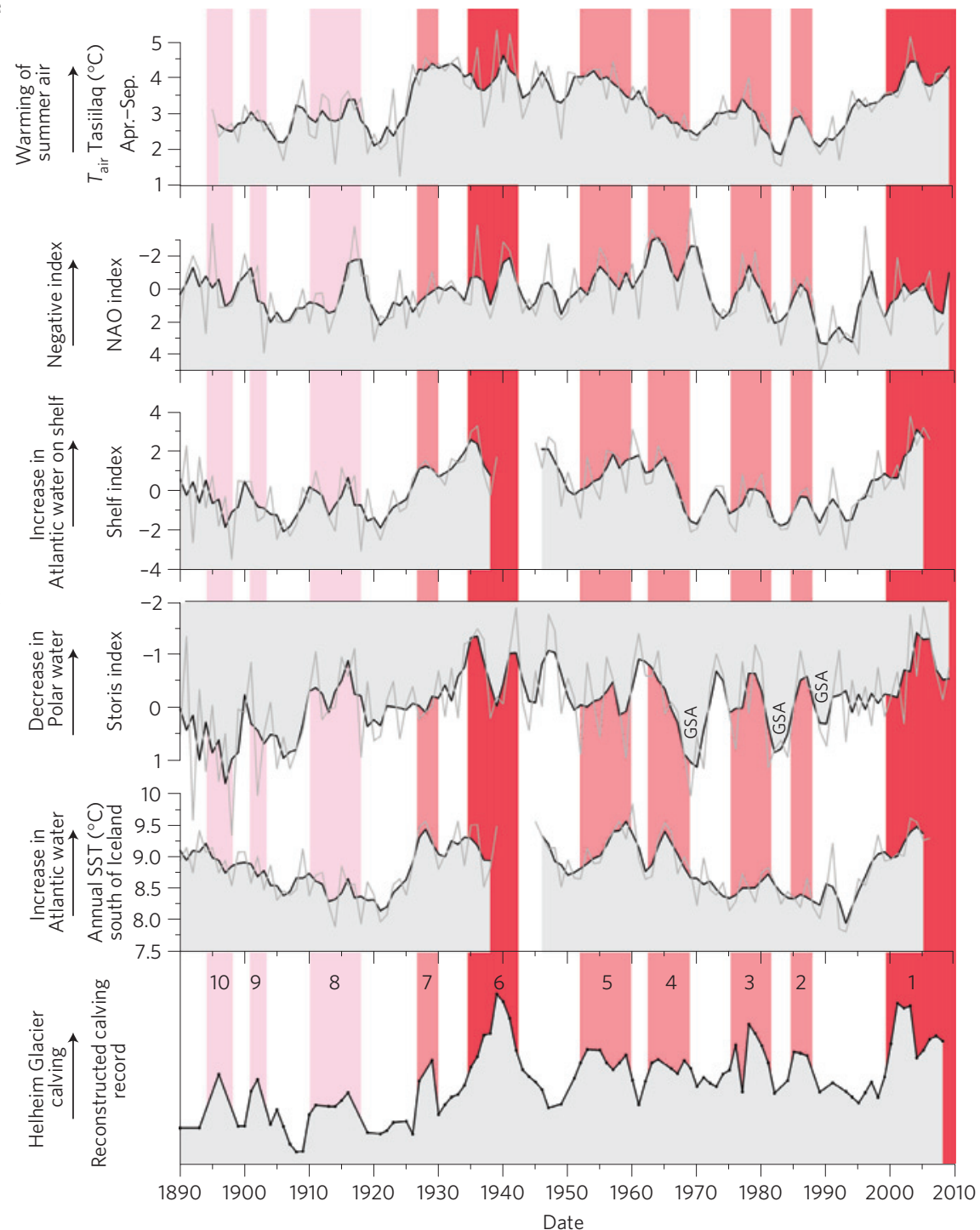

Figure 3 | Comparison between calving record and climate indices. a, Reconstructed calving record of Helheim Glacier. The grey line is unfiltered data. Increased calving events ( $\mathrm{HC1}-\mathrm{HC} 10)$ are highlighted in red (intensity of calving indicated by different shading) and correspond to the residual variability. b. Annual mean SST for an area south of Iceland (20-30 W, 60-63 N; Supplementary Information). c, Storis index ${ }^{25}$. GSA, Great Salinity Anomaly. d, Shelf index (normalized Atlantic water temperature and storis index weighted 1:1). e, NAO winter time index ${ }^{27}$.f, $T_{\text {air }}$ summer (April-September) in Tasiilaq $^{26}$. For b-f, black lines are 3-year running mean data and the grey line is unfiltered data.

Table 1 | Pearson correlation coefficients between calving and climate indices.

\begin{tabular}{llllll}
$r$ value with calving & $\boldsymbol{T}_{\text {air }}$ summer & NAO index & Storis index & Atlantic water $\boldsymbol{T}_{\text {annual }}$ & Shelf index \\
\hline Bulk data $(r \geq 0.29)$ & 0.45 & -0.45 & -0.36 & 0.38 & 0.41 \\
Multi-decadal variability $(r \geq 0.74)$ & 0.73 & -0.53 & -0.61 & 0.72 & 0.69 \\
Intra-decadal variability $(r \geq 0.29)$ & 0.24 & -0.42 & -0.18 & 0.27 & 0.29 \\
\hline
\end{tabular}

Climate data were applied with a 3-yr running mean and all data were linearly detrended before computing $r$ values (bulk data). Multi-decadal variability was highlighted by 25 -yr low-pass Fourier filtering and intra-decadal variability was obtained as a residual after subtracting the low-pass-filtered time series from the bulk data. For bulk data and residuals $r$ values $\geq 0.29$ are statistically significant and for the low pass-filtered data $r$ values $\geq 0.74$ are statistically significant at the $95 \%$ level. See also Supplementary Information

\section{Methods}

Core chronologies were established by measuring the ${ }^{210} \mathrm{~Pb}$ and ${ }^{137} \mathrm{Cs}$ activity and mass accumulation rates were estimated. Grain size distribution was analysed by a Malvern Mastersizer 2000 laser particle sizer. The cumulative volume percentage was determined for the clay and silt fraction $(<63 \mu \mathrm{m})$ and the sand fraction $(63-1,000 \mu \mathrm{m})$. X-ray radiography (Supplementary Fig. S1) and grain size analysis (Supplementary Fig. S3) of the cores reveals diamicton facies in all three cores with a mean content of sand of $9 \%, 22 \%$ and $18 \%$, in cores ER13, ER07 and
ER11, respectively, reflecting a more condensed stratigraphy of the two last cores. Sand deposition rates (iceberg rafting) were estimated as the flux of sand grains $\left(\mathrm{g} \mathrm{m}^{-2} \mathrm{yr}^{-1}\right)$ and the composite was produced as an average of the three cores. For documentation of past glacier margin positions, images from satellite and aerial photographs were geo-referenced using ortho-rectified aerial photographs from 1981 with a 2-m spatial resolution. Time series of annual mean SST for an area south of Iceland $\left(20-30^{\circ} \mathrm{W}, 60-63^{\circ} \mathrm{N}\right)$ were constructed using mainly the ICES database (www.ices.dk) and are used as a proxy for Atlantic-water temperatures. A time series 
of maximal multi-year sea-ice extent along southwest Greenland in May, June and July was used as a proxy for the volume of polar water. The shelf index was produced by normalizing these proxy records and further subtracting the resultant polarwater index from the Atlantic-water index. The Pearson correlation coefficients between the calving record and climate indices were calculated by filtering the data with a 3-yr running mean (except the calving record). All data were linearly detrended and a 25-year low-pass Fourier filter was applied to differentiate between longer- and shorter-term variability. The residuals were estimated by subtracting the low-pass-filtered data from the 3-year filtered and linearly detrended data set. A detailed description of the methods is given in the Supplementary Information.

Received 21 June 2011; accepted 14 November 2011; published online 11 December 2011

\section{References}

1. Rignot, E. \& Kanagaratnam, P. Changes in the velocity structure of the Greenland Ice Sheet. Science 311, 986-990 (2006).

2. Joughin, I., Abdalati, W. \& Fahnestock, M. Large fluctuations in speed on Greenland's Jakobshavn Isbræ glacier. Nature 432, 608-610 (2004).

3. Luckman, A., Murray, T., de Lange, R. \& Hanna, E. Rapid and synchronous ice-dynamic changes in East Greenland. Geophys. Res. Lett. 33, L03503 (2006).

4. Stearns, L. A. \& Hamilton, G. S. Rapid volume loss from two East Greenland outlet glaciers quantified using repeat stereo satellite imagery. Geophys. Res. Lett. 34, L05503 (2007).

5. Howat, I. M., Joughin, I. \& Scambos, T. A. Rapid changes in ice discharge from Greenland Outlet Glaciers. Science 315, 1559-1561 (2007).

6. Box, J.E., Yang, L., Browmich, D.H \& Bai, L-S. Greenland ice sheet surface air temperature variability: 1840-2007. J. Clim. 22, 4029-4049 (2009).

7. Holland, D. M., Thomas, R. H., de Young, B., Ribergaard, M. H. \& Lyberth, B. Acceleration of Jakobshavn Isbrae triggered by warm subsurface ocean waters. Nature Geosci. 1, 659-664 (2008).

8. Murray, T. et al. Ocean regulation hypothesis for glacier dynamics in southeast Greenland and implications for ice sheet mass changes. J. Geophys. Res. 115, F03026 (2010)

9. Joughin, I. et al. Ice-front variation and tidewater behavior on Helheim and Kangerdlugssuaq Glaciers, Greenland. J. Geophys. Res. 113, F01004 (2008).

10. Nick, F. M., Vieli, A., Howat, I., M. \& Joughin, I. Large-scale changes in Greenland outlet glacier dynamics triggered at the terminus. Nature Geosci. 2, 110-114 (2009).

11. Straneo, F. et al. Rapid circulation of warm subtropical waters in a major glacial fjord in East Greenland. Nature Geosci. 3, 182-186 (2010).

12. Straneo, F. et al. Impact of fjord dynamics and glacial runoff on the circulation near Helheim Glacier. Nature Geosci. 4, 322-327 (2011).

13. Mernild, S. H. et al. Freshwater flux to Sermilik Fjord, SE Greenland. Cryosphere 4, 453-465 (2010).

14. Syvitski, J. P. M., Andrews, J. T. \& Dowdeswell, J. A. Sediment deposition in an iceberg-dominated glacimarine environment, East Greenland: basin fill implications. Glob. Planet. Change 12, 251-270 (1996).

15. Dowdeswell, J. A. et al. An origin for laminated glacimarine sediments through sea-ice build-up and suppressed iceberg rafting. Sedimentology 47, 557-576 (2000).

16. Mugford, R. I. \& Dowdeswell, J. A. Modeling iceberg-rafted sedimentation in high-latitude fjord environments. J. Geophys. Res. 115, F03024 (2010).

17. Amundson, J. M. et al. Ice mélange dynamics and implications for terminus stability, Jakobshavn Isbræ, Greenland. J. Geophys. Res. 115, F01005 (2010)
18. Jennings, A. E. \& Weiner, N. J. Environmental changes in eastern Greenland during the last 1300 years: Evidence from foraminifera and lithofacies changes in Nansen Fjord, $68^{\circ}$ N. Holocene 6, 179-191 (1996).

19. Zwally, H. J. et al. Surface melt induced acceleration of Greenland ice-sheet flow. Science 297, 218-222 (2002).

20. Andersen, M. L. et al. Spatial and temporal melt variability at Helheim Glacier, East Greenland, and its effect on ice dynamics. J. Geophys. Res. 115, F04041 (2010).

21. Benn, D. I., Hulton, N. R. J. \& Mottram, R. H. 'Calving laws', 'sliding laws' and the stability of tidewater glaciers. Ann. Glaciol. 46, 123-130 (2007).

22. Motyka, R. J. et al. Submarine Melting of the 1985 Jakobshavn Isbrae Floating Ice Tongue and the triggering of the current retreat. J. Geophys. Res. 116, F01007 (2011).

23. Thomas, R. H. et al. Substantial thinning of a major east Greenland outlet glacier. Geophys. Res. Lett. 27, 1291-1294 (2000).

24. Schmith, T. \& Hansen, C. Fram strait ice export during the nineteenth and twentieth centuries reconstructed from a multiyear sea ice index from Southwestern Greenland. J. Clim. 16, 2782-2791 (2003).

25. Cappelen, J. (ed.) DMI Daily Climate Data Collection 1873-2010, Denmark, The Faroe Islands and Greenland-Including Air Pressure Observations 1874-2010 (WASA Data Sets) DMI Technical Report 11-06 (DMI, 2011).

26. Hurrell, J. W. Decadal trends in the North Atlantic Oscillation: Regional temperatures and precipitation. Science 269, 676-679 (1995).

27. Warren, C. R. Iceberg calving and the glacioclimatic record. Prog. Phys. Geogr 16, 253-282 (1992).

28. Schlesinger, M. E. \& Ramankutty, N. An oscillation in the global climate system of period 65-70 years. Nature 367, 723-726 (2004)

29. Dickson, et al. The Arctic Ocean response to the North Atlantic Oscillation. J. Clim. 13, 2671-2696 (2000)

30. Belkin, I. M. Propagation of the 'Great Salinity Anomaly' of the 1990s around the northern North Atlantic. Geophys. Res. Lett. 31, L08306 (2004).

\section{Acknowledgements}

This study has been supported by Geocenter Denmark in financial support to the SEDIMICE project. C.S.A. was supported by the Danish Council for Independent Research | Nature and Universe (Grant no. 09-064954/FNU). F. Straneo was supported by NSF ARC 0909373 and by WHOI's Ocean and Climate Change Institute and M.H.R. was supported by the Danish Agency for Science, Technology and Innovation. We thank Y. O. Kwon for insightful discussions on the climate data analysis and K. K. Kjeldsen for help with the digital elevation model image.

\section{Author contributions}

A.P.A., C.S.A. and A.K. conceived the study and C.S.A. and N.N-P. conducted fieldwork. C.S.A. is mainly responsible for data interpretation and sediment core data analysis and led the writing of the paper. F. Straneo contributed expertise on oceanography, statistical analysis and data interpretation and M.H.R. provided the oceanographic data compilation south of Iceland and updated the storis index from 2000 to 2008 . A.A.B. and K.H.K. are responsible for glacier image analysis. T.J.A. measured the ${ }^{210} \mathrm{~Pb}$ and ${ }^{137} \mathrm{Cs}$ activities. F. Schjøth compiled bathymetry data into the map. All authors contributed to data interpretation and writing of the manuscript.

\section{Additional information}

The authors declare no competing financial interests. Supplementary information accompanies this paper on www.nature.com/naturegeoscience. Reprints and permissions information is available online at http://www.nature.com/reprints. Correspondence and requests for materials should be addressed to C.S.A. 